\title{
On Collaboration
}

\section{Government Documents and Political Collections in Libraries and Museums}

\author{
Sandy Staebell and Sue Lynn McDaniel
}

Government documents librarians, special collections librarians and museum curators should collaborate. When they do, researchers and students benefit. While government documents tend to report the beginning and the end of the political process, political ephemera, artifacts and manuscripts provide a deeper understanding of what happens in between. Knowledge of readily available political collections equips information specialists to better serve users. Our survey reveals several U.S. academic institutions that provide online access to significant political collections. A close examination of the Rather-Westerman Political Collection at Western Kentucky University demonstrates how some university-held political collections are created, utilized and further developed.

M any university libraries and museums house primary sources for comprehensive research of American politics. Government documents establish the framework for understanding political processes and decisions. Usage of political collections, whether national or statewide in scope, helps fill in the details. Cross-training and knowledge of other resources enable government documents librarians, museum curators and special collections librarians to provide access to all things political.

\section{Survey of American Political Collections}

Cornell University's collections are perhaps the most important. Its cornerstone, the Susan H. Douglas Political Americana Collection, consists of an estimated 5,500 American political ephemera and commemorative items dating from 1789 to 1960. ${ }^{1}$ The Artstor Digital Library provides access to it at the item level. As of spring 2019, Cornell has acquired nearly 400 pieces of campaign literature for its Rare Books Collection and an additional 1,500 items for 12 other collections.

The Southern Methodist University (SMU) Libraries and Oklahoma State University (OSU) Libraries both use CONTENTdm collections management software to manage their digital collections. Viewers can browse SMU largest collection of political memorabilia, the Hervey A. Priddy Collection of American Presidential and Political Memorabilia, by chronology, form/genre and series. ${ }^{2}$ The results include more than 500 examples dating from 1833 to 2017. At OSU, users can sort more than 4,300 items in the Edna Mae Phelps Political Collection by title, date and subject. ${ }^{3}$ The website's menu offers eight shortcuts-Campaign Buttons, Pin-Back Buttons, Oklahoma, Women's Rights, Republican Party, Democratic Party, Political Collectibles and Oklahoma State University.

At Harvard's Kennedy School Library, the Political Buttons at HKS Collection offers scholars and teachers access to 1,600 political buttons with strengths in twentieth-century politics; electioneering; and social, political and cultural issues and movements. ${ }^{4}$ Access to the collection is possible through Hollis Images, the school's dedicated image catalog, which "includes content from archives, museums, libraries, and other collections throughout Harvard University." This catalog, like Western Kentucky University's online library catalog, uses Primo as its digital gateway.

The libraries of Duke University and Syracuse University house major political ephemera collections. Duke's Kenneth Hubbard Collection of Presidential Campaign Ephemera (30 linear feet) combines three-dimensional memorabilia and twodimensional paper ephemera dating from 1840 to $2016 .{ }^{6}$ Due to its size, the Duke librarians catalog this collection at box level. Syracuse, on the other hand, uses folder level description for its Campaign Collection (five linear feet) of "ribbons, campaign literature, posters, photographs, [and] clippings."”

Striving to promote an awareness of political campaigns and politicians, Regis University Special Collections created a library guide for the Notarianni Political Collection. ${ }^{8}$ Drawing from 3,000 items documenting presidential campaigns from 1796 to 2008, it served as the basis for a 2008 exhibit that lives online today.

The librarians at the University of Massachusetts Lowell Library took a different approach. Their library guides point 


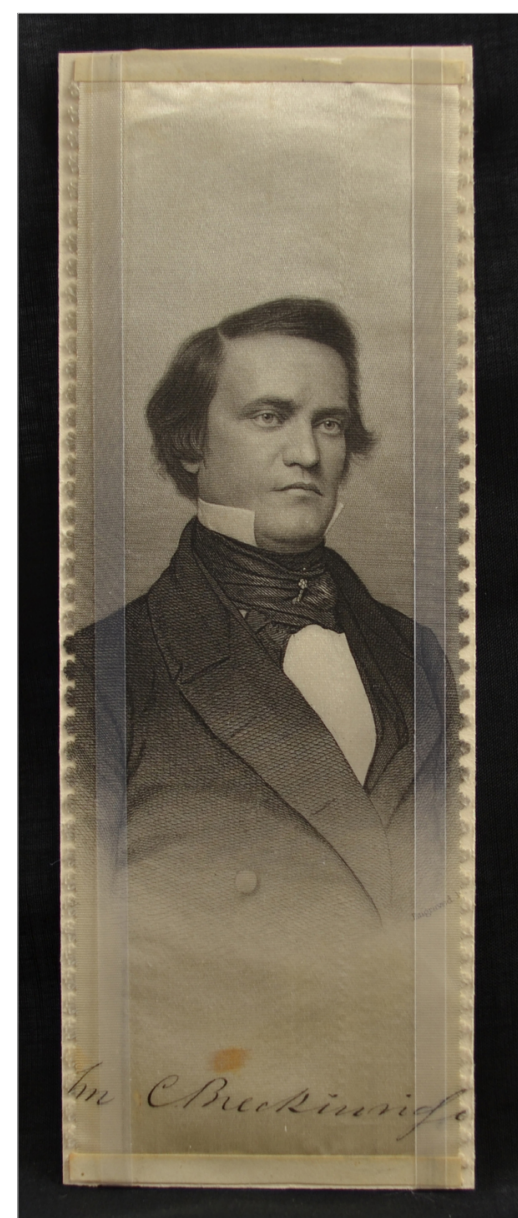

Figure 1. John C. Breckinridge Political Ribbon 1860. https://westernkentucky university.pastperfectonline.com /webobject/11A01E67-D152-40BB -9EEF-745351419170.

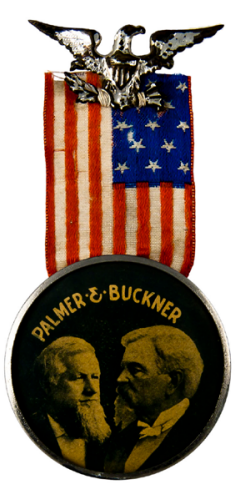

Figure 2. Palmer/Buckner Political Photo Ribbon 1896. https://westernkentucky university.pastperfectonline .com/webobject/040E4919 -OBCF-4294-83BC-181424 739077.

researchers to six collections of political memorabilia, only one of which the library owns. Collectors directly affiliated with the Lowell campus assembled two of them; a third was scanned from the Congressional Archive of former Massachusetts 3rd District Congressman Martin T.

Meehan; and politically active collectors created the remaining two. These research guides consist of digital surrogates that include images and brief object identifications. Except for the Meehan Collection, all are arranged alphabetically by candidate. ${ }^{?}$

\section{Survey of Kentucky Political Collections}

The state supported academic landscape in Kentucky includes two R1: Doctoral Universities—the University of Kentucky (UK) and University of Louisville (U of L) - and five comprehensive universities-Western Kentucky University (WKU), Murray State University (MSU), Northern Kentucky University, Eastern Kentucky University (EKU) and Morehead State University. Six out of seven special collections units in these academic institutions house political collections. These holdings typically consist of manuscript and print correspondence to, from or about politicians and their activities; newspaper clippings; photographs; and oral histories. They less frequently

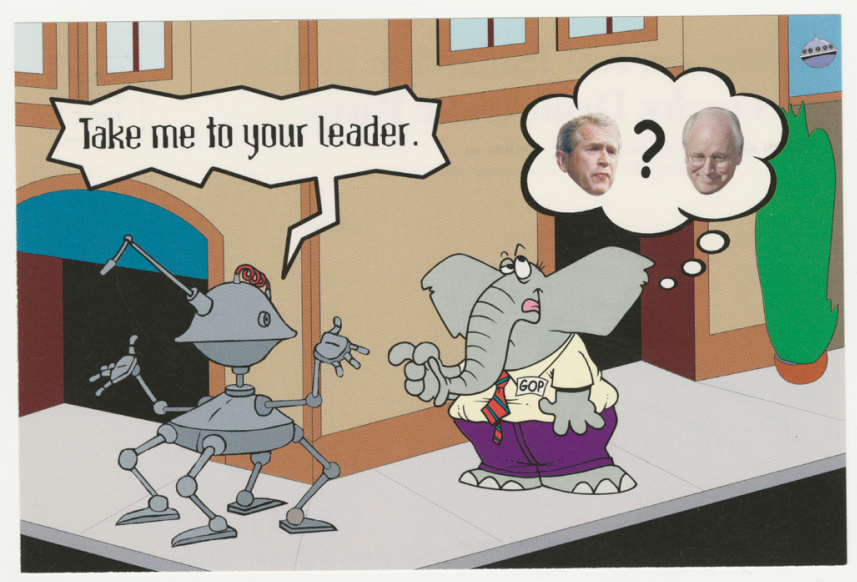

Figure 3. "Take me to your leader" [postcard]. https://westernkentucky university.pastperfectonline.com/archive/84E0C722-EF3B-434C -B98A-384304011070.

house political ephemera and memorabilia. Taken together, these collections cover local, state and national campaigns and issues.

Dating between 1832 and 1976, UK's Special Collections houses unique items in its Political Campaign Buttons, etc. Collection. ${ }^{10}$ Somewhat alike in its focus on state and national races, this collection lacks the breadth and depth WKU's holdings. Due to the box level of cataloging, the online finding aid defines the nature of the materials (political buttons, pins, ribbons, brochures and bumper stickers), housed in 12.18 cubic feet, but provides no details. The U of L's Archives and Records Center houses political collections that are a "part of the collective memory of the Louisville Metropolitan area, the Commonwealth of Kentucky, and the United States of America."11

The holdings at MSU consist of manuscript collections and more than 20 oral histories. EKU Special Collections is home to more than 35 political collections. Three of the five comprehensive universities house the papers of a major political figure: Governor Edward T. Breathitt (MSU), U.S. Representative Carl Perkins (EKU) and Congressman Tim Lee Carter (WKU). Remote access generally includes online collection descriptions and finding aids.

Within Kentucky two historical societies have significant political holdings. The Kentucky Historical Society collections are composed chiefly of manuscript materials and three-dimensional artifacts. A gem, the Drexell R. Davis Collection, includes more than 2,200 examples of three-dimensional memorabilia. ${ }^{12}$ Filson Historical Society users can access almost 1,600 manuscript collections relevant to political research. For information about related holdings in its museum, one must contact the Filson's Collection Department. 


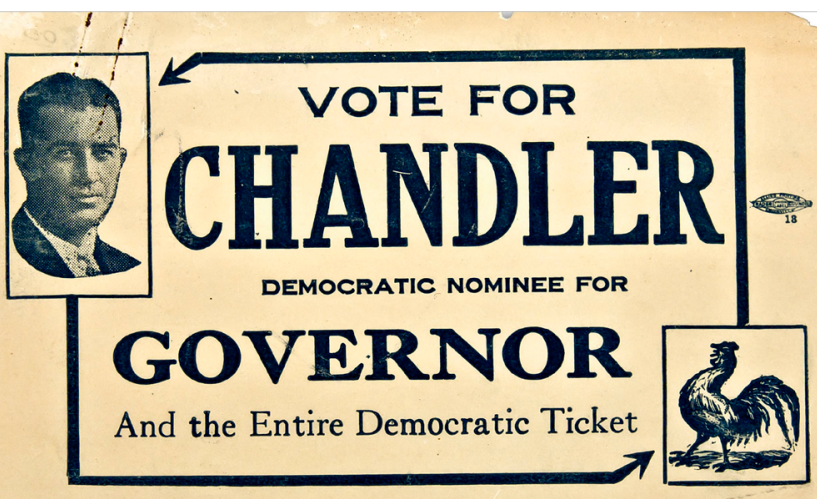

Figure 4. "Vote for Chandler" [political handbill] 1935. https:// westernkentuckyuniversity.pastperfectonline.com/archive/9B6AC1BE -A145-46AB-A6F1-149151576069.

\section{WKU's Rather-Westerman Political Collection (RWPC)}

Serving as a principal gateway to knowledge about the Commonwealth's political past and present, the Rather-Westerman Political Collection houses nearly 7,000 items dating from 1830 to the present. ${ }^{13}$ The time span and diversity of memorabilia illustrates politics at the local, state and national level. They document how individuals and communities come into conflict, form connections and ultimately govern.

The $R W P C$ contains many unique items. Kentucky's two most recognizable politicians, Abraham Lincoln and Henry Clay, are represented in the form of sheet music, ribbons, correspondence, engravings, medals, broadsides and a military promotion certificate. Two of our rarest items are pieces of Henry Clay sheet music, the only known copies. Among the textiles, a banner welcomes Kentucky governor Earle C. Clements and a hand-painted silk necktie promotes the election of President Harry S. Truman and Vice President and Kentucky native Alben Barkley.

Concerning political organizations, the Republican and Democratic parties are best represented. Memorabilia from the lesser known Whig, Gold Democrats, Know Nothing (American), Populist, Prohibition, Socialist, Communist, Independent, Tea and Green parties adds unique insights. The slogans and symbols on this material illustrate the way candidates distill their messages. Prominent issues include coal, marijuana, labor rights, minority rights and temperance.

Beginning in the 1930s, WKU accepted items about Kentucky politicians involved in state, county and local campaigns. When the collection outgrew faculty offices, administrators allocated space in the library for that purpose. Since 1939, the Kentucky Building has been the home of Library Special Collections (https://tinyurl.com/y5e52m3z) and the Kentucky Museum (https://tinyurl.com/y4uzpczq).

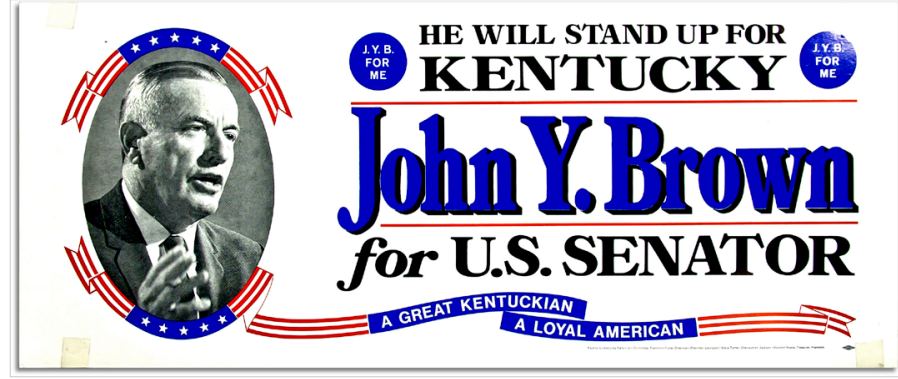

Figure 5. "John Y. Brown for Senator" 1966. https://westernkentucky university.pastperfectonline.com/archive/1286C6B2-1CC9-40ED -B8D8-830376015650.

The largest portion of the $R W P C$ reflects the collecting passion of two WKU alumni. In 1983, Lexington attorney Julius Rather began donating items from his collection with the goal of seeing these materials preserved and accessible for study. As a charter member of Political Americana Collectors of Kentucky (PACK), he gathered ephemera and artifacts from across the Commonwealth, sometimes purchasing unique and often costly historical items. In a 2011 interview, he defined his collecting scope as Kentucky politicians and national candidates campaigning within the Commonwealth. ${ }^{14}$

Louisville businessman Robert Westerman, also a WKU alumnus and PACK member, began donating primarily Louisville metro items in 1998. First interested in political memorabilia as a teenage campaign worker, he described his evolution as a collector:

"Initially, I had little interest in KY political memorabilia and always sold it to a friend and fellow WKU grad, Julius Rather. After a number of years of doing this, Julius asked me if I would make a commitment to him to continue to collect memorabilia for Western. As I did so, my primary collecting interest did become Kentucky items, particularly Kentucky

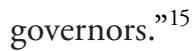

In recent years, the staff honored these two major donors by assigning $R W P C$ to all political ephemera and artifacts regardless of their source. Other significant contributors included journalist Allan Trout and political science professor John Parker. The latter, a retired WKU faculty member, finds primary sources an essential part of the curriculum. He believes "campaign memorabilia often encapsulate a political campaign's strategy ... [and] mark shifting political trends and electoral fortunes and changing campaign techniques." ${ }^{\text {16 }}$

\section{Other WKU Political Collections}

In addition to the Rather-Westerman Political Collection, WKU holds more than 450 manuscript collections relevant to politics. ${ }^{17}$ Citizens, candidates and elected officials offer unique points of view regarding national, state and local politics. Of 


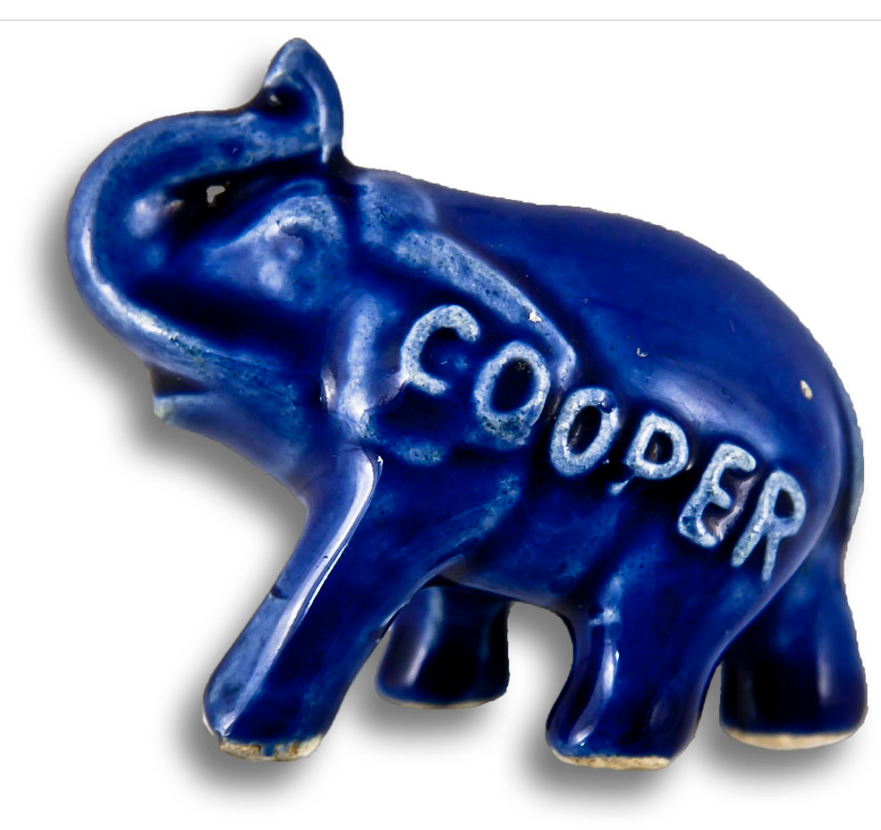

Figure 6. John Sherman Cooper Political Novelty 1948-1960. https:// westernkentuckyuniversity.pastperfectonline.com/webobject/5D76E438 -4938-4252-9D37-335998451490.

particular interest are the papers of four Congressmen who served during the nineteenth and twentieth centuries. The highlight of Whig Senator Joseph Rogers Underwood's career was his service as an 1844 presidential elector for Kentuckian Henry Clay. At the local level, Elizabeth Cox Underwood kept her husband abreast of statewide politics. Concerning Kentucky's proposed 1850 constitution, Mrs. Underwood apprised the Senator of the positions of Euclid Covington and David Rice Atchison who have both "taken to the stump." She noted that Covington, who championed the cause of the poor, referred to the rich as the "children of [the] devil." 18

One hundred years later, Frank L. Chelf served 11 terms in the U.S. House of Representatives. The papers of this selfdescribed "most conservative member of the Kentucky delegation" reflect the complex social and political challenges America faced from the mid-1940s through the mid-1960s. ${ }^{19}$ Congressman Tim Lee Carter's papers document a Kentucky physician's contributions to the national dialogue on the Vietnam War and legislation affecting healthcare, food, drugs, Social Security and clean water and air between 1965 and 1981. First elected in 1953, Representative William H. Natcher kept detailed journals throughout his legislative career and held the record for consecutive votes cast in the U. S. House of Representatives: 4,191 quorum calls and consecutive 12,644 roll-call votes.

Special Collections repositories typically limit their holdings of government documents to inaugural, memorial and commemorative publications. Museum curators and special collections librarians must identify holdings that will make

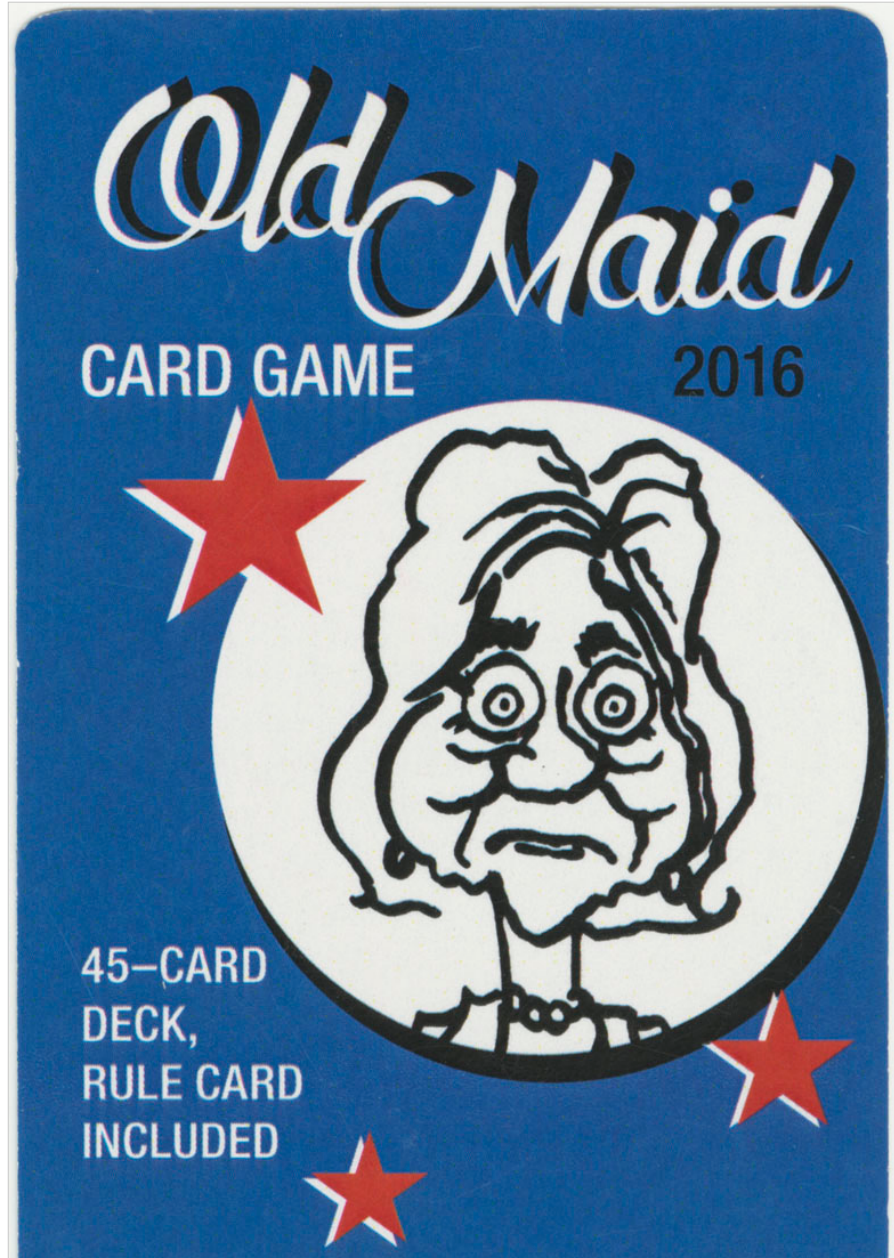

MADE IN U.S.A. @2016 CARDINAL LETTERPRESS LLC

Figure 7. Old Maid Card Game 2016. https://westernkentuckyuniversity .pastperfectonline.com/archive/DD72AA35-9C7E-4EBA-8739 -705303246230 .

unique contributions to scholarship. Kentucky appraiser J. Michael Courtney asserts that "No other institution in Kentucky, public or private, has anything close to the Rather Collection's buttons, bumper stickers, posters, sheet music, pamphlets and printed materials in terms of the variety and dates covered." ${ }^{20}$

The papers of "pistol packing" Pearl Carter Pace offer a feast of unusual paraphernalia collected during her nine years of service as a Republican National Committeewoman from Kentucky. ${ }^{21}$ Editorial cartoons, particularly those drawn by WKU alumnus Bill Sanders, offer pointed, often biting, commentary on American politics.

\section{RWPC Access}

For most of its history, intellectual control and access to the $R W P C$ was limited. Over the last 36 years, gift agreements for donations from Rather and Westerman described the contents 


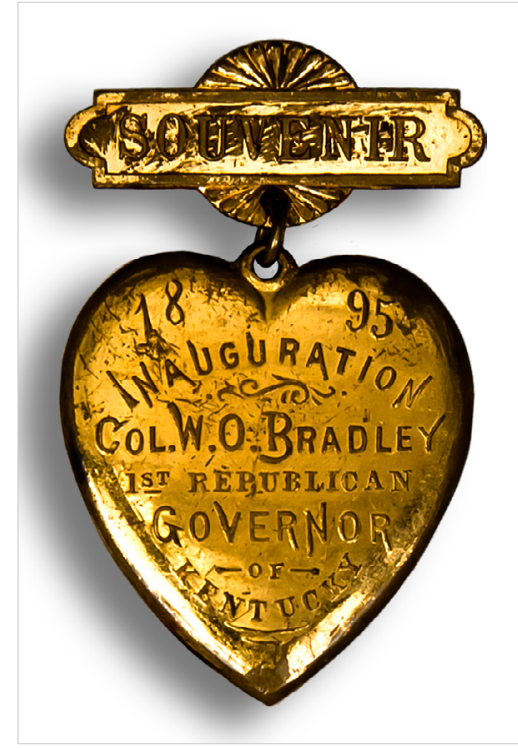

Figure 8. William O. Bradley Inaugural Souvenir Pin 1895. https://western kentuckyuniversity.pastperfectonline .com/webobject/C927A555-9A50-4274 -AC1B-305287973488.

\section{Kentucky Museum personnel began to manage accession-} ing, cataloging and retrieval of their collections using PastPerfect Museum Software (https://tinyurl.com/3hjzdvo). Two years later, they purchased its web-publishing tool, PastPerfect Online, and began uploading selected content into KenCat, their shared online catalog. ${ }^{22}$ End users can go directly to KenCat to view the collection, or they can access it via the Primopowered WKU Libraries catalog. Initially, all cataloging and data entry occurred at the item level. Beginning in 2018, manpower limitations and program goals for the upcoming 2020 presidential election dictated that Special Collections' personnel catalog $R W P C$ ephemera at the folder level. Staff continue to retro-catalog all donations received prior to 2006.

While off-campus researchers and WKU faculty and students can request hands-on access to the $R W P C$, the staff increasingly directs them to use KenCat for their initial research. We suggest research strategies that include requests for hands-on access to specific items; make them aware of primary sources not yet in the public catalog; and refer them to government documents and other institutional collections.

\section{Promoting the Rather-Westerman Political Collection}

Strategies for promoting awareness and use of the $R W P C$ encompass traditional methods. To promote usage by WKU faculty and students, further education of library faculty and staff who provide government documents reference services is necessary. This training will include instruction on all materials accessible through KenCat. Further collaboration with research assistance librarians and subject specific faculty will enhance existing research guides.

The ephemeral nature of modern communication poses new challenges for documenting today's history for tomorrow's scholars. Operating as a "for more information" tactic, Facebook, Twitter, Instagram and blog posts promote awareness of our collections. Besides raising the profile of the $R W P C$, WKU Library Special Collections and Kentucky Museum faculty use social media to promote donations and research.

WKU's first major use of social media as a collection development tool grew out of the need to document the political and social climate during and after the 2016 presidential campaign. Recognizing that a rapid response was required to document the rallies, protests and demonstrations, we created the America United/America Divided Project (AU/AD Project). It focused on collecting materials that reflect Kentuckians' participation in rallies, campaigns, inauguration, causes and marches. Thus, we documented the diversity of political, religious, social, cultural and scientific opinion expressed in the United States between the fall of 2016 and February of 2018.

Efforts to solicit donations for the AU/AD Project included traditional and modern approaches. We contacted student, local and regional political organizations and representatives via phone and email. College and local media outlets promoted it. We created a Facebook page and messaged the Facebook pages of local activist organizations. Personnel attended marches, took digital photos and personally requested the donation of materials. Staff took photos at the March for Science and Climate, International Women's Day March, Unity March (the Trump Administration's ban on Muslims entering the United States) and March for Our Lives.

Unlike mass produced buttons, bumper stickers and magnets that uniformly convey a candidate's message, the items and quotes collected for the AUIAD Project typically expressed the personal beliefs of individual citizens. Kentuckians communicated their personal perspectives through print and digital photographs, homemade clothing, posters, banners and video recordings. A prime example was a banner created in response to a Trump Administration official's reference to the purported "Bowling Green Massacre." ${ }^{23}$ By the project's end, the archive consisted of several hundred items. Most donations came from individuals who felt left out or unrepresented after the election despite our efforts to stress the non-partisan nature of the project. 


\section{Teaching}

Comprehensive research requires an understanding of both action and reaction. Government Document repositories house official government records that result from political activity. Special collections repositories and museums house materials that express citizens' actions and reactions. Neither can stand alone. Campaign materials often capture the economic, racial and social underpinnings reflected in American society. ${ }^{24}$

Recently hired teaching faculty are often more receptive to collection-based curriculum and research initiatives. To complement classroom instruction, professors often request unique object-based lectures. Political Science and History faculty have responded positively to these latest outreach efforts. In the fall of 2018, the "Women and Politics" class used the RWPC for an object-based lecture followed by individual research assignments on female politicians. Dr. Victoria Gordon's students "reported that this experience opened their eyes to history in a new way and inspired them to run for office and to volunteer for political campaigns." 25

History Professor Kate Brown requested an object-based lecture for her American Revolution/Early Republic course. Following the presentation, she noted that "adding a study of early-republic material culture to the familiar historical narrative ... underscored for them just how saturating politics was then (as now) in everyday life. ... These artifacts ... struck my students as real history-that is, a tangible, non-abstract and vital way to understand how early republican politics infused the discourse of nineteenth-century America." 26 Based on this feedback, other faculty may request access to this set of manuscripts, artifacts and ephemera.

Library and museum faculty broaden use through structured learning opportunities that emphasize access to primary sources. Maximizing limited personnel resources, the Museum Education Curator reviews course syllabi to focus our outreach on faculty who teach subject-relevant classes with large enrollments. This criterion informed our recent close study package focused on World War I/World War II. Targeted faculty received a list of collection materials featured in the package and a schedule of available time slots. Following most library and museum faculty presentations, instructors required students to research one or more of the featured artifacts.

The majority of library and museum faculty continue to provide personalized instruction to enhance research skills. They help students define research projects, recommend search strategies and identify potential sources.

\section{Unique Faculty and Staff Contributions}

University faculty bring knowledge and perspective to our collections. Individuals whose expertise complements them provide ongoing advice regarding collection development and exhibits. In the fall of 2019, eleven faculty from nine departments developed object lessons for Out of the Box, an exhibit showcasing South Central Kentucky's unique culture and heritage. Participants were selected following the Museum Educator's review of WKU programs and course syllabi to identify classes that addressed the basic thematic areas of the exhibit, i.e., Music, Religion, Entrepreneurship, Medicine, and Caves. Participating faculty received a list of artifacts that could be used to illustrate these themes and were free to suggest additional potential items for interpretation. Ultimately, an Art faculty member wrote three object lessons, Folk Studies and Geography faculty members wrote two each and the remaining faculty contributed one object lesson apiece. Intended to represent collection strengths, this exhibition fosters multidisciplinary discussions about Kentuckians' collective heritage

WKU Library Special Collections and Kentucky Museum faculty publicize student internship opportunities. Their projects are designed to benefit collection needs while satisfying curriculum requirements. Students work with supervising library and museum faculty to define their tasks and determine the required minimum number of hours. In order to receive course or internship credit, they typically spend an average of 120 hours on their project. In addition, some internships require a paper or oral presentation. Historically, most internships are unpaid. However, donors have funded several scholarships in recent years.

In 2018, a student seeking a Master's degree in Public Administration scoured the Rather-Westerman Collection to create an Access database of Kentucky women politicians. Museum faculty will use this database in planning efforts for exhibits. One year later, a Special Collections student assistant processed ephemera while a Folk Studies graduate intern evaluated memorabilia for possible use in political exhibits. A graduate assistant and an undergraduate student assistant created fact sheets on Kentucky female politicians. Through exhibit research and construction, internships, independent study projects and volunteer opportunities, these students contribute knowledge, perspective and man-hours.

The next year, the Political Science Department, Library Special Collections, the Kentucky Museum and our county public library received grant funding to underwrite Journey to the Vote, a series of programs marking the 100th anniversary of the 19th Amendment to the U.S. Constitution. Through this 
project, Dr. Gordon stated that we are ensuring opportunities for WKU students and the community "to not only gain a greater understanding of political concepts, but access documents and artifacts and experience learning at a much deeper level." 27

\section{Planning for the Future}

The challenges are many and unfortunately remain constant. Given limited or non-existent funds for the targeted acquisitions, institutions often rely on the generosity of donors whose collecting interests may not match their collecting scopes and needs. Personnel changes usually influence an organization's collection development focus over time.

Collection planning must reflect the changing nature of political collections as politicians move from traditional threedimensional objects and printed materials to newer, often electronic, formats. Although bumper stickers, buttons, caps and T-shirts remain popular, today's candidates prefer door hangers, mass mailings and social media; they have little use for neckties, kerchiefs and thimbles. Changing societal norms also affect the use of certain types of materials as vehicles for conveying political messages. For example, the association of matchbooks with smoking may have decreased their usage. Born-digital primary sources not only require specialized capture methods, but also need constant upgrades to the latest accessible format. The abundance of image capturing software programs creates additional challenges in digitizing physical artifacts and keeping them accessible electronically.

Collection development must consider the human factor. Focused on their love of past politics, collectors sometimes require family pressure or tax write-offs to part with their treasures. With luck, the risk of future dispersals of their collections will motivate collectors of ephemera and artifacts to place their possessions in a repository. Grieving families often contact libraries and museums. Librarians and curators must educate and pursue politicians, political action committees and issuedriven organizations who prioritize the present over their legacy. Limited funding often results in passive collecting. Building quality collections requires a commitment to planning, personnel and financial resources.

Strongly held political beliefs on the part of collectors, donors and institutional personnel can and do shape acquisitions. Evolving attitudes towards politics and generational differences will influence future collecting of political memorabilia and commemoratives. PACK's declining membership and its members' observations indicate that younger Kentuckians have little interest in collecting political memorabilia. Considering these factors, librarians and curators need to exercise diligence, a sense of urgency and diplomacy to build collections.

In response to a change in WKU's leadership, a new strategic plan and decreased funding, Kentucky Museum and Special Collections personnel have increased their outreach efforts to WKU faculty and students. We document our collections' relevance to the university's academic mission. Today's students communicate through social media. To reach them, librarians and curators must adapt to their ever-changing modes of communication.

Collections in academic libraries, museums and historical societies are uniquely positioned to complement government documents. Study of their holdings facilitates an understanding of how politics operates at the local, state and national level. The use of government documents, political ephemera and artifacts strengthens our awareness of the United States political system, past and present. When government documents librarians, special collections librarians and museum curators work together, society benefits.

Sandy Staebell (sandy.staebell@wku.edu), Associate Professor, Library Special Collections, Kentucky Museum Registrar \& Collections Curator and Western Kentucky University. Sue Lynn McDaniel (sue.lynn.mcdaniel@ wku.edu), Professor, Special Collections Librarian, Western Kentucky University.

\section{References}

1. "Collection of Political Americana," Cornell University Library, Cornell University, https://tinyurl.com /yxdu96cv.

2. "Hervey A. Priddy Collection of American Presidential and Political Memorabilia," SMU Libraries, Southern Methodist University, https://tinyurl.com/y5lhsske.

3. "Edna Mae Phelps Political Collection," Edmon Low Library, Oklahoma State University, https://tinyurl.com lyyb26upq.

4. "The Political Buttons at HKS Collection," Harvard Kennedy School, Harvard University, https://tinyurl.com ly5pmc85o.

5. HOLLIS Images, Harvard Kennedy School Library and Knowledge Services, Harvard University, https://tinyurl .com/yxpgbqpu.

6. "Guide to the Kenneth Hubbard Collection of Presidential Campaign Ephemera, 1840-2016 and undated," 
Duke University Libraries, Duke University, https:// tinyurl.com/y5jz3oez.

7. "Campaign Collection," Syracuse University Libraries Special Collections Research Center, Syracuse University, https://tinyurl.com/y2pn48bs.

8. "Notarianni Political Collection," Regis University Library, Regis University, https://tinyurl.com/y672pwzb.

9. "Political Memorabilia Collections," UMass Lowell Library Guides, UMass Lowell, https://tinyurl.com ly3jp8s7b.

10. "Political Campaign Buttons, etc. Collection, University of Kentucky Libraries, University of Kentucky, accessed, https://tinyurl.com/y528eype.

11. "Political Collections: Home," University of Louisville University Libraries, Archives \& Special Collections, https://tinyurl.com/y4bk4wwu.

12. "Artifacts Catalog," Kentucky Historical Society, https:// tinyurl.com/y4slutun.

13. "Rather-Westerman" keyword search, Kencat, Library Special Collections and Kentucky Museum, Western Kentucky University, https://tinyurl.com/yywsbjes.

14. Rather, Julius. Interview by Sue Lynn McDaniel. Lexington, KY, June 14, 2011.

15. Robert Westerman, email message to Sandra L. Staebell, January 21, 2019.

16. John Parker, email message to Sue Lynn McDaniel, January $8,2019$.

17. TopSCHOLAR, Western Kentucky University, accessed September 15, 2019, https://tinyurl.com/y4koxptv.

18. Elizabeth Cox Underwood to Joseph Rogers Underwood, April 28, 1850, Underwood Collection, Library Special Collections, Western Kentucky University.
19. Richard Harwood, "Persistence His Weapon in Congressional Combat: Once He Starts After A Goal, Chelf Is A Fighter None Can Stop," Louisville Times, January 31, 1962.

20. J. Michael Courtney, email message to Sue Lynn McDaniel, January 9, 2019.

21. Louise Hughston, "Straight Shootin' Pearl Always Hits the Bullseye," Washington Post, January 24, 1960.

22. "KenCat Online Collections," Library Special Collections and Kentucky Museum, Western Kentucky University, https://tinyurl.com/y4y9cz4l.

23. "KenCat Online Collections," Library Special Collections and Kentucky Museum, Western Kentucky University, https://tinyurl.com/y4lrau54; Samantha Schmidt and Lindsey Bever, "Kellyanne Conway cites Bowling Green massacre' that never happened to defend travel ban," Washington Post, Feb. 3, 2017, https://tinyurl.com /y5eakv6f or BGDN, Feb. 3, 2017; "SLIDE SHOW: Bowling Green massacre remembrance gathering," Bowling Green Daily News, February 3, 2017, https://tinyurl .com/y3u 9s9pt.

24. "KenCat Online Collections," Library Special Collections and Kentucky Museum, Western Kentucky University, https://tinyurl.com/y3lmq6bg.

25. Dr. Victoria Gordon, email message to Sandra L. Staebell, January 3, 2019.

26. Dr. Kate Brown (WKU Historian), email message to Sandra L. Staebell, January 24, 2019.

27. Gordon, email message to Sandra L. Staebell, January 3, 2019. 